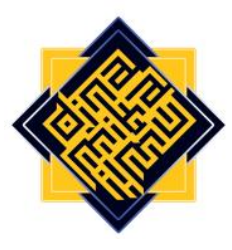

\title{
Santri's Humility in the Salafiyyah Islamic Boarding School
}

\author{
Azam Syukur Rahmatullah \\ Universitas Muhammadiyah Yogyakarta, Indonesia \\ e-mail:azam.sy@umy.ac.id \\ Muhammad Azhar \\ Universitas Muhammadiyah Yogyakarta, Indonesia \\ e-mail:muazar@yahoo.com \\ Ahmad Fajruddin Fatwa \\ Universitas Islam Negeri Sunan Ampel Surabaya, Indonesia \\ e-mail: andifajruddinfatwa@gmail.com
}

\section{Abstract}

This research belongs to qualitative research, which explored the santri's humility (tawadhu') in the Lirboyo Islamic Boarding School, Kediri. Tawadhu' in Islamic boarding school is traditional, rooted, and has become a positive character. Thus, it deserves to be explored and later can be used as a "role model" for other educational institutions to implement, develop and produce individuals with this character. The method used was field research with an ethnomethodological approach, a cluster of qualitative research that focused on reality with practical interpretation. Research results showed that the notion of tawadhu', in the kyai's perspective at the Lirboyo Islamic Boarding School, Kediri, was an effort to transfer values and morality to the santri. Thus, they would possess polite behavior, obey goodness and virtue, will be kind to others. Second, tawadhu' had several foundational factors at the Salafiyyah Lirboyo Islamic Boarding School, East Java, including (a) spiritual foundations, (b) struggling mental foundations, (c) prosocial foundations. The objectives of tawadhu' for the santri at the Salafiyyah Lirboyo Islamic Boarding School, East Java, were: (a) growing value education in the students, (b) Preventing self-deception and misdirection to others, (c) building and instilling muhsin's personality to the students. Creating the teachings of tawadhu' at 
Azam Syukur Rahmatullah et al.

the Lirboyo Islamic Boarding School, Kediri was influenced by several factors: (a) the kyai's charisma, (b) the continuous book learning, and kaffah internalization to students. Many teachings have educated students in the books studied to be humble, obedient, and glorify others.

Keywords: humility, Lirboyo Islamic Boarding School Kediri, tawadhu'

\section{A. Introduction}

Academics and scholars have been discussing education practitioners, including teachers, educators, instructors, regarding their moral crisis, fading etiquette taught at school but not practiced in daily life (Herlangga, 2017). This situation is known as "barren ethics" or "barren morality." Today's educated people are more inclined to cognitive enrichment with various efforts to educate the brain rather than spiritual enrichment and spiritualization in the soul and mind. Whereas ethics and manners are included in "inner enrichment" and a concrete form of "inner spiritualization", which is called the term "social piety."

Thus, the embedding of the word "educated" becomes ambiguous because "educated people" means educated in the cognitive-mathematical aspects and "whole holistic or comprehensive", such as affective, social, and spiritual aspects. If this complete package is pinned to the students, then the "educated people" label should fit. Somehow, this reality is confusing as many educated students still have a crisis of manners, selfmorality, and Javanese customs. Students who adopt lousy behavior may have problems during the learning process at school, at home, and in the surrounding environment (Putrihapsari \& Dimyati, 2021).

Some problems include internalizing teaching and education, which may experience obstacles during transferring values and morals to students (Achlami, 2018). This failed process causes students not to perceive, interpret, and appreciate and enter the "failed meaning area". Hence, their behaviors lack ethics. The second problem that causes deviant behavior is the school or madrasa curriculum, which focuses only on brain-based material mastery, leaving the morals and inner enrichment of the students. Various school materials tend to educate the brain than to educate the soul, where in fact, the center of morals is on the intelligence of the soul and the mind. These issues are rarely found in public schools, even madrasas, even though they teach much religious material. They are still more on the side of brain enrichment than manner enrichment. What is being pursued is learning materials or values rather than children's morals and character.

Students nowadays lack respect for teachers, parents, adults (Budiutomo, 2014). The humility (tawadhu') crisis includes how young ones do not want to address the elders first. Second, students refuse to lower their heads in front of parents, teachers, and other elders 
and raise their heads to show self-arrogance. Third, students look away when seeing older people and teachers. Fourth, students refuse to kiss the elderly's hands while shaking hands. Fifth, they raise their voice while talking to the elderly, and sixth, they do not respond when called. Seventh, they pretend not to recognize their teachers outside the classroom (Munir, 2019).

The various acts mentioned reveal that not all educational institutions are willing and able to realize consistent and prolonged tawadhu'. Tawadhu', which educational institutions-especially the public, sometimes create is only temporary, does not leave an impression. There is no emphasis and deep meaning so that what happens is "camouflage of disgrace", meaning submission, obedience, and humility are only around schools, madrasas. Still, after leaving school, they leave it and show self-arrogance.

Pesantren or Islamic boarding schools have a tawadhu' tradition that is different from public educational institutions. One of them is the salafiyyah pesantren, which has a vital characteristic related to building its students sincere in doing tawadhu' without any conditions, polite without asking for rewards, and its prolonged nature (Hanafi, 2018). Even until the end of the study period in the pesantren, tawadhu's principles are still imprinted. Compared to modern pesantren, salafiyyah pesantren have more solid in the tawadhu' culture, meaning that the highlight is similar wherever salafiyyah pesantren are located.

Why is the tawadhu' character of the santri in the salafiyyah pesantren almost the same and unique? A kyai and the foundation of all activities comes from a santri who stays at a salafiyyah pesantren (Amal, 2018). This situation, in the end, makes a positive character for the kyai, who has been a santri carried over at any time. Thus, when a kyai establishes his pesantren, he will apply the tawadhu' tradition exactly as he studied earlier. Thus, tawadhu' tradition of the santri in the salafiyyah pesantren is hereditary.

One of the old salafiyyah Islamic boarding schools, which does not doubt its quality and credibility in Islamic boarding schools, is the Salafiyyah Lirboyo Islamic Boarding School, Kediri, East Java. As one of the prominent, charismatic, and influential Islamic boarding schools in Java, this pesantren remains consistent in establishing tawadhu' for the santri (Interview with Ust Mubaidi Sulaeman, March 2, 2021). In the Salafiyyah Lirboyo Islamic Boarding School in Kediri, tawadhu' is absolute and mandatory. It is a sincere habit for the students because the proper position of tawadhu' is above knowledge or the result of seeking knowledge is tawadhu'. Thus, tawadhu' is higher than just seeking knowledge. There is concern from the Liboyo Kediri Islamic Boarding School, which is becoming more modern, the more self-deprecating it becomes. This condition also strengthens the pesantren to continue teaching and educating its students about tawadhu' teachings, which can also be used as a fortress, shield, and crown in behavior (Interview with Ust Mubaidi Sulaeman on March 2, 2021).

Based on this strengthening consistency, the Lirboyo Kediri Islamic Boarding School is worthy of being a role model for other educational institutions regarding tawadhu'. Therefore, the researchers want to explore more deeply about the tawadhu' of the santri from the salafiyyah Islamic boarding school's perspective, which in this case is the Lirboyo 
Azam Syukur Rahmatullah et al.

Islamic Boarding School Kediri. The results can be used as additional knowledge in general and Islamic Educational Psychology related to teaching tawadhu' to children and students.

\section{B. Literature Review}

Etymologically, tawadhu' means humble in Arabic. In addition, other words mean place or location. While in Indonesian etymology, the word tawadhu' means humble and obey. Tawadhu', from the views of Al-Ghazali (1995), is to exclude one position and consider other people are more critical. Tawadhu', for Athoillah (2019), means growing and witnessing Allah's majesty and the glory of His nature.

Nata (2001) proposes that tawadhu' is a process of activities applied to change a person to be more optimistic by enriching self-character. Meanwhile, Al-Zarnuji (1995) argues that tawadhu' makes a person more organized in his soul, humble, generous, away from arrogant attitudes and behavior with various efforts and curricula or anything that directs children towards habituation full of humility. Miskawaih (1329) stated that tawadhu' is the process of heart cleansing, by which he will lead himself to righteous behavior without self-conceit and full of humility.

According to Dzunnun Al Misri, some indicators of respectful attitude are; first, humble people do not like to be considered necessary by others; second, not proud when walking accompanied by other people; third, not ashamed to sit with disabled people. Fourth, he does not keep a distance from people who are sick and disabled; fifth, it is light to serve others in everything; sixth, always working on their needs (not always commanding); seventh, willingness to wear simple clothes.

\section{Research Methodology}

This research is field research, systematically by collecting data from the Lirboyo Islamic Boarding School, Kediri, East Java. The researchers directly came to the location to get the necessary data. The approach used was an ethnomethodological approach Garfinkel (1967), whose data mining is descriptive, derived from observations of a speech, writing, action, and behavior of the subject observed at the Lirboyo Islamic Boarding School, Kediri, East Java. The setting of this research is at the Lirboyo Islamic Boarding School, Kediri, East Java. There are several reasons why the researchers picked Lirboyo Islamic Boarding School; first, this boarding school is an old boarding school and recognized by the community with thousands of students and thousands of alumni who had tawadhu' as a manifestation of the teachings of the pesantren. Second, this pesantren is an old salafiyyah, which has taught santri devotion and piety for years. Third, this boarding school has a formula or model for applying tawadhu' to the santri, which can later be adopted (emulated) by other pesantren or public institutions. In other words, the application of tawadhu' at the Lirboyo Islamic Boarding School can be a role model for Islamic boarding schools and other than Islamic boarding schools to develop tawadhu' for children jointly.

The subject selection used a purposive sampling technique with a snowball model. The informants consisted of several positions: the board of directors of the pesantren or 
the kyai; the santri advisory council composed of senior ustadz who correctly understand the santri's various problems; the administrators who are in direct contact with the students; the administrator of the student room, who takes care of the students for 24 hours; and residents around the pesantren, who may have accurate and reliable information. Data collection techniques were carried out in several ways, including participant observation, in-depth interviews, documents. The data obtained were then analyzed descriptively and interpreted the data. In contrast to other research approaches, in the ethnomethodology approach, the description and interpretation of the data were carried out since the first data collection. The analysis was continuous and simultaneous (cycle). Thus, a proper conclusion will be drawn. There are several ways to do descriptive analysis, namely: First, the data in the form of a detailed description of each research subject is read one by one by the researcher. Second, reading the data for each description, basically, the researcher is doing an analysis of sorting out the "natural" statements of each research subject. Third, the results of the analysis are rewritten in the form of a description in accordance with the reality of the results of focused interviews and on the basis of the meaning of the research subject, not the opinion of the researcher. Fourth, the results of the description are in line with the research objectives/problems and must be in line with the understanding of the meaning of the research subjects in relation to their living environment. Fifth, find a description in the form of a statement that is in line with the understanding of meaning by the subjects in their group or ethnic life (Fatchan, 2015).

\section{Results and Discussion}

1. Understanding Tawadhu' from Kyai's Perspective at Lirboyo Islamic Boarding School, Kediri

Lirboyo Islamic Boarding School, Kediri, is an old and historical institution with charisma and significant influence inside and outside Java Island. This boarding school was established in 1910 AD, which does not doubt its role in developing Islamic teachings. Besides, it has many uniqueness and characteristics, which are not owned by many other educational institutions, such as:

\section{a. A high spiritual climate}

Lirboyo Islamic Boarding School Kediri is a boarding school with a spiritual climate. One indicator of the "spiritual climate that has become a culture" can be seen from the many studies of classical books there. The distinctive culture of book study with Sorogan and Bandongan has become a tradition of salafiyyah pesantren rich in the spiritual aura. Various books are taught starting from the Ibtidaiyah, Tsanawiyah, Aliyah, and I'dadiyah levels, all based on the yellow book, with positive character enrichment. Since establishing the pesantren, the spiritual climate at the Lirboyo Islamic Boarding School has indeed formed and deeply rooted, which is characteristic of salafiyyah pesantren and not many other Islamic educational institutions have. 
Azam Syukur Rahmatullah et al.

b. A culture of tawadhu' of the students and stakeholders

Tawadhu' culture is not easy to create, adapt and teach to students in an educational institution. It requires a great struggle to make the culture of tawadhu' unique character grounded for students. Many educational institutions fail to turn students into mutawadli' in individuals (tawadhu' experts). Many institutions can only lead their students to become intelligent people in mind, but not spiritually wise, and instead show their scientific and academic arrogance. At the Lirboyo Islamic Boarding School, Kediri, tawadhu' has been instilled and taught with politeness, submission, and obedience that has strengthened the santri since the beginning, and this consistency has continued.

What appears at the Lirboyo Islamic Boarding School in Kediri is that tawadhu' is not only between the santri to the kyai and their teachers. It is also between the santri to their seniors, teachers/junior asatidz to the senior teachers/asatidz, and the teacher council/junior asatidz, teachers /asatidz old kyai. Tawadhu' has spread to all stakeholders or the community in the pesantren, without any barriers, ranks, and degrees. Kyai remains the "central figure" who is managed and respected by the people of the cottage. A figure who can present "a stunning example deserves to be followed by his advice and sincerely obeyed" without any conditions. Kyai is also the initial and primary moderator of tawadhu' who is also the leading figure who provides a consistent direct example to his students. Therefore, the kyai fully understands the functionality, usefulness, and significance of the tawadhu' culture in the pesantren.

Kyai of the Lirboyo Islamic Boarding School, Kediri, proposes that tawadhu' is interpreted as a "self-nobility", which comes from the Arabic word wadh'a or condescending, while ittadha'a means humble. One of Kyai Lirboyo, Haji Anwar Manshur, stated that:

"Tawadlu' adalah merendahkan diri dari sifat-sifat al-hayawaniyyah (kebinatangan) yang salah satunya adalah sifat sombong (al-takabbur); sombong kepada diri sendiri, sombong kepada sesamanya, dan juga sombong kepada makhluk lain, terlebih lagi adalah sombong kepada Sang Hyang Pencipta ". (Wawancara pada tanggal 13 Maret 2021)

"Tawadhu' is to humble oneself from al-hayawaniyyah (animalism), arrogance (al-takabbur) to oneself, other humans, and other creatures, or Allah. (Interview on March 13, 2021)

According to the Kyai Haji Anwar Manshur, tawadhu' depends on how a person's daily behavior is, whether they are arrogant. Arrogant people will show anti-social behavior and do not understand how to honor each other. Thus, the behavior exhibited is of low ethics and does not show humility to each other.

Meanwhile, Kyai Haji Kafabihi Mahrus stated that:

"Tawadhu' has a noble and high degree because it shows the depth of his knowledge. People who are tawadhu' are people who can internalize the teachings of the knowledge gained into themselves to show polite behavior, glorify others, stay away from greatness in life. (Interview on March 16, 2021) 
Tawadhu' conveyed by Kyai Haji Kafabihi Mahrus is that it is at a high level of nobility and distances itself from the principle of adigang adigung adiguna, which is arrogant and selfish. If someone has deviant doctrines, he will fall into the condescending type. Therefore, tawadhu' must be taught, created, and internalized into anyone who feels "human" by teaching tawadhu'. Kyai Haji Anwar Manshur stated that:

"Pendidikan ketawadlu'an sejatinya adalah upaya mentransfer nilai dan etikadalam diri seseorang yang dalam hal ini adalah kaum santri, agar mereka tahu bagaimana caranya bersikap yang sopan dan santun, bagaimana cara bertutur kata yang lembut, serta bagaimana memuliakan sesama. Karena kemuliaan seseorang itu terletak pada akhlak. (Wawancara pada tanggal 13 Maret 2021)

"Tawadhu' education transfers values and ethics of santri so that they know how to be courteous, speak softly, and honor others. Because a person's glory lies in morals. (Interview on March 13, 2021)

Based on Kyai Haji Anwar Manshur's statement above, tawadhu' education is intrapersonal and interpersonal intelligence translations. A person is taught how to behave, speak words, behave, which makes others amazed, relaxed and does not make other people thrive on his su'udzan, but on the contrary, his husnudzan thrives.

From the definition of tawadhu' by the kyai above, several elements can be drawn from it, including (a) a process of transferring values and morals to someone, making a person change for the better; (b) changing oneself so that words, temper, actions, and attitudes showing kindness; (c) based on sincerity in acting without any tendencies and any conditions; (d) Unplanned and artificial behavior.

Those above definitions, it is in line with the results of Purnama Rozak's (2017) research which states that the indicators of tawadlu'an come from the essence of the definition of tawadlu'an. Where the tawadlu'an indicator provides an overview of the actual tawadlu'an, and the condition of the tawadlu'an that a person should have and be consistent with someone.

\section{Factors of Santri's Tawadhu' at the Salafiyyah Lirboyo Islamic Boarding School, East Java}

Lirboyo Islamic Boarding School, Kediri has a strong character, which not all modern boarding schools or public schools have. The characteristic is the grounded teachings of tawadhu' (Junaidi, 2019). This habit of tawadhu' has taken root and become a tradition at the Lirboyo Islamic Boarding School, even since its founding. It is slowly but surely built by the founder or the kyai.

The kyai's hard struggle at the beginning has become increasingly visible and a positive habit that is "hereditary" to this date(Amal, 2018). The students who are so sincere in practicing tawadhu' without refusal or criticism. They carry out full awareness, no burden, surrender to the kyai, dzuriyyah, senior, and junior asatidz councils, all of which can be absorbed and internalized by the students. Thus, after graduation, they will always apply tawadhu' wherever they go.

Dinamika Ilmu, Volume 21(2), 2021 
Azam Syukur Rahmatullah et al.

Kyai Haji Kafabihi Mahrus stated that:

"Tawadhu' was deliberately instilled by the predecessors by adopting the excellent culture of the pesantren where the founders studied and brought by the noble teachings to the established pesantren. In the end, this good culture became a positive tradition enforced without any conditions at Lirboyo Islamic Boarding School, Kediri." (Interview on March 16, 2021)

Tawadhu' is inherited from the previous pesantren, where the kyai recites the Koran and knowledge. Hence, it "continues" in teaching goodness and virtues related, which in the end becomes an excellent positive habit, and becomes jariyah for the kyai, teachers, and educators (Ma'arif, 2010). Related to tawadhu' for the students at the Lirboyo Islamic Boarding School, Kediri, several factors cause it, including:

Figure 1

Factors of Santri's Tawadhu' at the Salafiyyah Lirboyo Islamic Boarding School, East Java

\section{Strengthening Qur'an and Hadith Translation}

A prove that tawadhu's main sources are

Al-Qur'an and Hadith

\section{Strengthening Intrapersonal Intelligence and Students' Interpersonal}

Students reading and translating Al-Qur'an become positive habit.

\section{Self-Protection for Santri from a Moral Crisis}

The boarding school provides ethical and moral teachings and is responsible for the students.

Source: Formulated from interviews with kyai

The first point, one factor of tawadhu' at the Lirboyo Islamic Boarding School Kediri, is the Qur'an and hadith that must be conveyed and translated into daily behavior. In this case, the founders and caregivers show that "true knowledge is above manner and morals" (al-science fauqo al adabi) (Masrur, 2017). Tawadhu' guides students to be civilized human beings with morality and knowledge all at once (Asyari, 2017). Many humans know but cannot internalize their understanding into themselves, causing a lack of manners and morals (Zaqiah \& Rusdiana, 2014). Knowledge without meaning is empty. It should be 
accompanied by a transmission and internalization process within oneself (Rahmatullah, 2017). If successful, it will produce individuals with knowledge and a positive character.

The second point is strengthening santri's intrapersonal and interpersonal intelligence (Rahmatullah, 2013). It is a self-introspection and nursery into the social world. Self-introspection educates oneself intrapersonally (intelligence from within). The nursery of the social world educates interpersonally (intelligence to the outside). Tawadhu' essentially directs and demonstrates the two bits of intelligence, called the intelligence of self-reflection (al-muhasabah bi an-nafsi) and social muhasabah (al-muhasabah li alghoirihi) (Mujib, 2006). Students are encouraged to be good at the Koran, study, internalize, and transmit other books. Thus, it is a discourse and an application at the same time.

The third point shows the culture of tawadhu' for the santri at the Lirboyo Islamic Boarding School, Kediri, which is due to the self-protection from the moral crisis. The founders and caretakers of the pesantren have realized and tried to fortify themselves from an early age because ethical problems have been worrying. Thus, if the students are not equipped with moral sciences, morality, tawadhu' and knowledge of submission to Allah, they may also be eroded by animalistic lust (an-nafs al-hayawaniyyah) behavior. This lust is far from people who are tawadhu' (Nurbakhsy, 1998).

Explanations above are irresponsible behavior towards oneself, which shows humility and a crisis of value education and attitudes and temperaments far from spiritual nuances and religion. There has not been a "harmonious interaction" and "cognitive dissonance" between worship behavior and daily behavior. The pesantren preventive actions then carry out this condition. Therefore, tawadhu' teaching is maximized by the Lirboyo Islamic Boarding School, Kediri.

One form of value education according to the research results of Rinita Rosalinda Dewi, Mupid Hidayat and Cik Suabuana (2021), is that it can be seen clearly from the tawadlu'an education that is sown by the students, which in this case is the harmony between values education and tawadlu' education. in which tawadlu'an education is rich in values education, and values education is fully illustrated in the habituation of tawadlu'an in pesantren.

Frisancho \& Delgado (2018) asserts that value and moral education can indeed seen in a real and direct manner with the civilizing of tawadlu'an in schools, educational institutions, which generally are strong Islamic educational institutions, mainly Islamic boarding schools. Therefore, value and moral education must continue to be cultivated and developed intensely so that noble personalities will be created.

\section{The Purpose of Tawadhu' for Santri at the Salafiyyah Lirboyo Islamic Boarding School, East Java}

As explained, tawadhu' at the Lirboyo Islamic Boarding School, Kediri, East Java, has been implemented for years, even rooted, imprinted deeply. Hence, the graduated students are remarkable. They grow into "mutawadli'in" individuals or experts that glorify themselves and others. 
Azam Syukur Rahmatullah et al.

There are several pure and noble goals why tawadhu' is applied and entered at the grounding level, which later grows into a positive character at the Lirboyo Islamic Boarding School, Kediri, including:

\section{a. Embedding Value Education to Santri}

Soelaeman believes that the value education is an activity for developing values through a systematic and critical process to improve students' cognitive and affective qualities (Zaqiah \& Rusdiana, 2014). Meanwhile, Kohlberg claims the value education fosters and develops the structure and potential for the affective experience or human identity or conscience with a set of moral values and norms (Sumantri, 2007).

Soelaeman and Kohlberg have a similar idea with the Lirboyo Islamic Boarding School, Kediri, where the boarding school fosters tawadhu' education to instill norms, values, and ethics into the students Allah His Messenger. Tawadhu' will also translate the conscience, which always says, declares, voices, and truth.

\section{b. Avoiding Self-Deception (dzālimun li an-nafsi) and Misleading Others (dzālimun li al- ghoirihi)}

Misguidance in Arabic or the language of the Qur'an is referred to as dalāl, which means lost, dead, hidden, in vain, perish, mistaken, or forgotten. Dalāl is interpreted as turning away from the straight and correct path (Al-Ragib, 2008). Misguidance (daläl) committed by a person can teach detrimental behaviors to oneself, and others called dzālimun li al-ghoirihi. He is not devoted to parents and teachers, constantly argues and does not care about parents and teachers, asocial to others, and various other misguided behaviors, all of which are far from tawadhu' (Rahmat, 2007).

The purpose of tawadhu' to the santri at the Lirboyo Islamic Boarding School Kediri is to avoid misguided behavior (dzālimun li an-nafsi) and (dzālimun li al-ghoirihi) that harm others because it violates the command of Allah SWT, as in OS. Al-Maidah:105, QS. AzZumar: 53, and QS. AS-Shaad: 26.

\section{c. Building and Growing Muhsin's Personality to the Santri}

Muhsin means a person who does ihsan. Abdul Mujib (2006), in his work entitled, Personality in Islamic Psychology, stated that ihsan means good. Muhsin's personality brings benefits (al-manfa'ah) and avoids harm (al-mudharat). Ihsan behavior can also be interpreted as good behavior, normal and not harming other people, and glorifying others.

The founders and caregivers of the Lirboyo Islamic Boarding School, Kediri, deliberately cultivate tawadhu' so that students naturally, without any conditions, can form positive habits, good and noble habits, which in the end possess muhsin behavior. By staying long enough at the pesantren, the students will hopefully own muhsin personality when they leave the boarding school.

There are several verses of the Qur'an used as the foundation of the pesantren including surrendering to Allah wherever they are (OS. Al-Baqarah: 112), making peace with self and others, being soft-hearted, having a highly empathetic temper, and treating everyone equally (OS. Al-Nisa: 128), not harming others (OS. Al-A'raf: 56) and repaying evil 
deeds with good deeds (QS. Yunus: 26).

\section{d. Educating the Santri to Humanizing Others}

The goal of "education" is to "humanize others" by transferring knowledge, values, and morals to move positively from arrogant behavior to gentle and humble behavior, from challenging behavior to embracing behavior, from abusive behavior to glorifying behavior. Darmiyati Zuchdi (2010) states humanization enriches oneself with morality and positive values to others.

In this case, Lirboyo Islamic Boarding School, Kediri has tried to teach its students how to humanize others by being humble, not antipathetic to others, not rioting, and being angry with their behavior who do damage and good for others. This is in line with value education in the framework of National Education. The essence of National Education is to bring children to the peak results of a process of seeking knowledge, namely morality, or noble morals (Khairuddin Y.M., 2017). A successful educational process actually leads to positive behavior change and will be manifested by behaviors that do not harm many people, but glorify others. One of its forms is to show tawadlu habits in daily life.

\section{Kinds of Tawadhu' of the Santri at the Salafiyyah Lirboyo Islamic Boarding School, East Java}

The researchers reveal that students and asatidz have practiced tawadhu'. Tawadhu' between the santri and the asatidz to the kyai and the santri to the asatidz is in Table 1.

Table 1: Kinds of Tawadhu' between the Santri and the Teacher Council / Asatidz to Kyai

\begin{tabular}{|c|l|l|}
\hline No. & \multicolumn{1}{|c|}{ Kinds of Tawadhu' } & \multicolumn{1}{c|}{ Description } \\
\hline 1. & Kissing the kyai's hand & $\begin{array}{l}\text { Kissing the kyai hand at the back of the hand } \\
\text { and the palm is a manifestation of ikhtirom, } \\
\text { as kyai is the leader of the pesantren, who has } \\
\text { a significant responsibility. }\end{array}$ \\
\hline 2. & $\begin{array}{l}\text { Bowing when the kyai passes, even when the } \\
\text { kyai is in a car, the santri are taught to ikhtirom, } \\
\text { bow down, and remain motionless }\end{array}$ & $\begin{array}{l}\text { The students should respect the elders or } \\
\text { people who have contributed significantly in } \\
\text { their lives, especially those who have } \\
\text { provided knowledge and morals in their lives. }\end{array}$ \\
\hline 3. & $\begin{array}{l}\text { When the kyai is walking, all the students will } \\
\text { stop and wait for him to pass while lowering } \\
\text { their eyes and head }\end{array}$ & $\begin{array}{l}\text { The students are taught not to put their } \\
\text { egotism forward to the experts of knowledge } \\
\text { and manner, to walk behind them as } \\
\text { conveyed in Ta'limu Ta'alim. }\end{array}$ \\
\hline 4. & $\begin{array}{l}\text { Taking out a prayer mat when the kyai wants } \\
\text { to lead the five daily prayers }\end{array}$ & $\begin{array}{l}\text { When the kyai leads the prayer, the students } \\
\text { begin to prepare prayer mats for the kyai to } \\
\text { walk. After the kyai arrives at the priesthood, } \\
\text { the prayer rug is rolled back and will be held } \\
\text { again when the kyai finishes leading the } \\
\text { prayer. }\end{array}$ \\
\hline
\end{tabular}


Azam Syukur Rahmatullah et al.

\begin{tabular}{|c|l|l|}
\hline 5. & $\begin{array}{l}\text { Staying silent when the kyai has not allowed or } \\
\text { has not opened question session when } \\
\text { teaching }\end{array}$ & $\begin{array}{l}\text { In front of the teacher, the students should } \\
\text { keep humble. It is also part of seeking } \\
\text { knowledge with manners and morals. }\end{array}$ \\
\hline 6. & $\begin{array}{l}\text { Respecting kyai's dzurriyah; his children, } \\
\text { grandchildren, and descendants }\end{array}$ & $\begin{array}{l}\text { Students should respect by speaking softly. } \\
\text { kyai's descendants are the direct blood of the } \\
\text { kyai, and therefore, they must be respected. }\end{array}$ \\
\hline 7. & $\begin{array}{l}\text { Preparing the sandals that kyai wears before } \\
\text { he goes anywhere }\end{array}$ & $\begin{array}{l}\text { When the kyai finishes praying, the students } \\
\text { should prepare the sandals immediately. }\end{array}$ \\
\hline 8. & Cleaning kyai's house and environment & $\begin{array}{l}\text { The students may sincerely clean the kyai's } \\
\text { house without tendency whatsoever, except } \\
\text { to serve the kyai as a gratitude for the } \\
\text { knowledge. }\end{array}$ \\
\hline
\end{tabular}

Table 2: Kinds of Tawadhu' between Santri to Teacher/Asatidz

\begin{tabular}{|c|l|l|}
\hline No. & \multicolumn{1}{|c|}{ Kinds of Tawadhu' } & \multicolumn{1}{|c|}{ Description } \\
\hline 1 & $\begin{array}{l}\text { Walking with head down when passing the } \\
\text { sitting teacher }\end{array}$ & $\begin{array}{l}\text { Showing respect for the teacher who has } \\
\text { given knowledge and etiquette to students, } \\
\text { teaching, and education is not only about } \\
\text { theory. }\end{array}$ \\
\hline 2 & Kissing the teacher's hand & $\begin{array}{l}\text { Teachers are supposed to kiss their } \\
\text { teachers' hands to show some respect and } \\
\text { devotion. }\end{array}$ \\
\hline 3 & Not passing the teacher while walking & $\begin{array}{l}\text { All students are taught to walk behind the } \\
\text { teacher. Even if a teacher passes, the } \\
\text { students must stop to let the teacher pass } \\
\text { first, and then the students can walk behind } \\
\text { him. }\end{array}$ \\
\hline 4 & $\begin{array}{l}\text { Speaking politely, not raising voice to sound } \\
\text { patronizing, and offend the teacher }\end{array}$ & $\begin{array}{l}\text { The students are trained to deal with and } \\
\text { talk to older people, especially those who } \\
\text { contribute to their lives. }\end{array}$ \\
\hline
\end{tabular}

Based on Table 2, tawadhu' teaches the students at the Lirboyo Islamic Boarding School Kediri several principles; (1) sincerity, meaning that the students are frank without any tendency or conditions to be devoted to kyai and teachers. Everything is to expect Allah's blessing through kyai and teachers; (2) self-awareness, meaning that the students are invited to enter the phase of self-awareness. In this phase, the students are devoted because what the kyai and teachers give is more valuable than anything, knowledge, and etiquette, so students return the favor by grounding them with humility and reverence; (3) blessing, the students, expect the blessing from Allah and their kyai or teachers.

The blessing itself is indeed taught by the Pesantren, and strongly instilled by the Sang Kyai. By referring to the teachings of the Qur'an which states that blessings are goodness that are continuous, and uninterrupted, and bring benefits. In line with the 
results of research by Ahmad Kusaeri (2017) who stated that true blessings are goodness that flows like water and continuously, and will bring a consistent behavioral impact in daily life, which shows inner well -being, peace of mind and peace of mind manifested in behavior.

\section{The Process of Tawadhu' at the Salafiyyah Lirboyo Islamic Boarding School, East Java}

Tawadhu' set at the Kediri Islamic Boarding School took a long time. This process is certainly not easy. Many parties have contributed to tawadhu' at the Lirboyo Islamic Boarding School, Kediri. Some of them are; the pesantren leader, the kyai, the central figure in the pesantren, whose words and actions become qudwah and role models (Amal, 2018). Their words are called sabda pandita kyai that the santri should follow to honor others (Masrur, 2017). The leaders of this boarding school are also fully responsible for tawadhu' in the pesantren. Thus, the policies set by the kyai will become a firm basis on how to implement and improve tawadhu' for the santri.

Second, the senior asatidz council or al-Ustadz Suyukh or the ustadz whose service has been around for many years from when they were young until they grow older. Of course, their role cannot be underestimated because the asatidz al-suyukh are also exemplary figures used as role models by the students. On the other hand, since the asatidz suyukh participated in being teachers, educators, and protectors, it was full of transferring values and morals to the students.

The third is senior administrators, who are students' direct 'bodyguards' of the students. They a significant role because they are the supervisors, enforcers of rules, and evaluators for students who do not practice tawadhu' in pesantren. Thus, the tawadhu' behavior remains well controlled and becomes a habit.

Tawadhu' at the Lirboyo Islamic Boarding School in Kediri is influenced by several aspects, including the kyai's charisma. As explained earlier, the influence of the kyai in the world of pesantren is significant. They become the central figure which determines the santri's behavior (Musaropah, 2018). The kyai is also a unique charm for the students. Even without being ordered, the students will submit and obey the kyai and show their devotion (Dhofier, 2011). In this case, the kyai has a strong aura, a unique attraction that not many others have. It can move the santri and all stakeholders to submit, obey, and follow the noble and positive commandment from the kyai (Mas'ud, 2004).

Second, book learning is continuous and kaffah internalization to the students (Bruinessen, 1995). In the books studied, many teachings educate students to be humble, obedient and glorify others. Book learning starts from the beginning when the students enter the boarding school. The Sorogan and Bandongan learning methods 'typical of salafiyyah pesantren' bring students closer to their teachers and make it easier for kyai and teachers to transfer values, making it more meaningful. There are several moral books taught to students based on their school level, as shown in Table 3. 
Azam Syukur Rahmatullah et al.

Table 3: The Study of the Book of Tawheed and Morals Based on Levels

\begin{tabular}{|c|c|}
\hline Level & Book of Tawheed \\
\hline Ibtidaiyyah Level & $\begin{array}{c}\text { Book of Tawheed } \\
\text { - } \quad \text { 'Aqidatul Awam } \\
\text { - Zadul Mubtadi' } \\
\text { - } \quad \text { Tauhid Jawan } \\
\text { Book of Morals (Akhlaq) } \\
\text { - } \quad \text { Taisirul Kholaq } \\
\text { - Nadhamul Mathlab } \\
\text { - Nadhamul Akhlaq Alala } \\
\text { - } \quad \text { Mitra Sejati }\end{array}$ \\
\hline Tsanawiyyah Level & $\begin{array}{c}\text { Book of Tawheed } \\
\text { - As-Sanusiyyah } \\
\text { - Khoridatul Bahiyyah } \\
\text { Book of Mornu Ibrahim al-Bajuri } \\
\text { - At-Tahliyah } \\
\text { - Washoya } \\
\end{array}$ \\
\hline Aaliyah Level & $\begin{array}{c}\text { Book of Tawheed } \\
\text { - Ummul Barohin } \\
\text { - } \quad \text { Kifayatul 'Awam } \\
\text { - Jauharoh at-Tauhid } \\
\text { Book of Morals (Akhlaq) } \\
\text { - Ta'limu Muta'alim }\end{array}$ \\
\hline I'dadiyah Level & $\begin{array}{c}\text { Book of Tawheed } \\
\text { - Matnu AS Sanusiyah } \\
\text { - } \quad \text { Matnu Ibrohim al Bajuri } \\
\text { Book of Morals (Akhlaq) } \\
\text { - } \quad \text { At-Tahliyah } \\
\text { - Taisirul Kholaaq } \\
\text { - Nadhmul Mathlab }\end{array}$ \\
\hline
\end{tabular}

Source: Documentation of the Lirboyo Islamic Boarding School, Kediri, Lesson Curriculum

Tawadhu' to the most vital students, uses wasilah learning the book of monotheism and morals (Thoriqussu'ud, 2012). Why the book of monotheism? It is because the basic foundation of morality is faith in Allah. The fear of Allah will lead to great reverence in life and foster submission to Allah so that the behavior shown in daily life will be carried positively so that the level of meaning will be high. Thus, monotheism becomes the basis of one's morals. With this monotheism, a person will be straight in his morals. 
Therefore, at the Lirboyo Islamic Boarding School, Kediri, monotheism and morality are two mandatory books. Combining the two books plus other books such as books on interpretation, hadith science, fiqh science, ushul fiqh science, mantiq books, and balaghoh books reinforce tawadhu' in pesantren.

This seeding of the teachings of books that have been around for years has made the process of tawadhu' education stronger, coupled with the climate of obedience, submission, and tawadhu' that has become a tradition in pesantren, making tawadhu' a character for the santri. Based on the explanation, it can be concluded that; (a) tawadhu' is a process created or conditioned by the pesantren (since its inception) in a long period which later became a habit; $(b)$ an attached figure becomes an example, a role model who has a charisma that can move and attract people to submit and obey, which is the figure of the kyai; (c) The kyai and asatidz teach a book of monotheism and morals. All of which are wasilah for forming the tawadhu' of the santri; (d) Jihad or a long struggle whose essential foundation is sincerity because Allah enforces rules based on tawadhu'.

\section{E. Conclusion}

Based on the results, tawadhu' according to kyai's perspective at the Lirboyo Islamic Boarding School, Kediri, is an effort to transfer values and morality to the santri. Hence, they have polite behavior to others and obey goodness and virtue. Several essential factors help to form tawadhu' at the Salafiyyah Lirboyo Islamic Boarding School in East Java, such as: first, the spiritual foundation, which is the basis of a struggle to get close and attached to Allah; second, the mental foundation of effort, which becomes a spirit to translate God's commandments; and third, prosocial foundation, which builds closeness and attachment to God and the society.

There are several goals for grounding tawadhu' at the Salafiyyah Lirboyo Islamic Boarding School in East Java: first, to value education in the students; second, to stay away from self-deception and misdirection to others; third, to build and instill muhsin's personality to the students. Tawadhu' (humility) of the santri at the Salafiyyah Lirboyo Islamic Boarding School in East Java to the council of teachers / asatidz to the kyai, include: kissing the kyai's hand, bowing, not walking in front of the kyai, taking out prayer rug when the kyai wants to lead the five prayers time, not asking before being allowed, respecting kyai's dzurriyah, preparing kyai's sandals, and cleaning the kyai's house. The humility of the santri to teachers/asatidz include: bowing down when passing the sitting teacher, kissing the teacher's hand, not walking in front of the teacher, speaking politely, not raising a voice, and offending the teacher. Tawadhu' at the Lirboyo Islamic Boarding School in Kediri is influenced by several aspects: kyai's charisma, continuous books, and kaffah internalization. In the texts studied, many teachings educate students to be humble, obedient, and glorify others. The hope in the future is that there will be tawadlu'an education that is seeded and taught to all students, not only those who are in the pesantren environment, but also those who are not in the pesantren. Thus, it will create individuals who are polite, and rich in self-morality. 
Azam Syukur Rahmatullah et al.

\section{BIBLIOGRAPHY}

Achlami HS, M. (2018). Internalisasi Kajian Kitab Akhlak Tasawwuf dan Pendidikan Karakter di Pesantren Al-Hikmah Bandar Lampung. Analisis: Jurnal Studi Keislaman, 18(1), 39-54. https://doi.org/10.24042/ajsk.v18i1.3302

Al-Ghazali, I. (1995). Ihya'Ulum al-Din Jilid III. Dar al-Fikr.

Al-Ragib, A.-A. (2008). Mu'jam Mufrodat al-Fadhil al-Qur'an. Dar Al-Kotob Al-Ilmiyah.

Al-Zarnuji, S. B. (1995). Ta'limul Muta'allim Tariq Al-Ta'allum. Mutiara Ilmu.

Amal, A. S. (2018). Pola Komunikasi Kyai dan Santri dalam Membentuk Sikap Tawadhu di

Pondok Pesantren Bahrul Ulum Tambakberas Jombang. INJECT (Interdisciplinary Journal of Communication), 3(2), 253-272.

Asyari, H. (2017). Pendidikan karakter khas pesantren. TSmart.

Athoillah, A. (2019). KH. Ali Maksum Ulama, Pesantren, dan NU. LKiS.

Bruinessen, M. Van. (1995). Kitab kuning pesantren dan tarekat Tradisi-tradisi Islam di Indonesia. Mizan.

Budiutomo, T. W. (2014). Membangun Karakter Siswa Melalui Pendidikan "Unggah Ungguh" Di Sekolah. Academy of Education Journal, 5(2), 53-70. https://doi.org/10.47200/aoej.v5i2.117

Dewi, R. R., Hidayat, M., \& Suabuana, C. (2021). Strategi Pendidikan Nilai Sebagai Pembentuk Kepribadian Siswa Di Sekolah. Jurnal Bidang Pendidikan Dasar, 5(1), 9-17. https://doi.org/10.21067/jbpd.v5i1.4495

Dhofier, Z. (2011). Tradisi Pesantren: Studi Pandangan Hidup Kyai dan Visinya Mengenai Masa Depan Indonesia. Pustaka LP3ES.

Fatchan, A. (2015). Metode penelitian kualitatif : pendekatan etnografi dan etnometodologi untuk penelitian ilmu- ilmu sosial (Cetakan 1). Penerbit Ombak.

Frisancho, S., \& Delgado, G. E. (2018). Moral education as intercultural moral education. Intercultural Education, 29(1), 18-39. https://doi.org/10.1080/14675986.2017.1405214

Garfinkel, H. (1967). Studies in ethnomethodology. Prentice Hall.

Hanafi, M. S. (2018). Budaya Pesantren Salafi (Studi Ketahanan Pesantren Salafi Di Provinsi Banten). ALOALAM, 35(1), 103-126. https://doi.org/10.32678/alqalam.v35i1.382

Herlangga, O. (2017). Faktor-faktor penyebab hilangnya perilaku santun dalam bingkai budaya Jawa (studi kasus pada seorang siswa SMP) [Universitas Sanata Darma]. http://repository.usd.ac.id/12138/2/121114062_full.pdf

Junaidi, K. (2019). Teaching System, Education Curriculum, and Education Quality Strategy in Pondok Pesantren Lirboyo Kediri City. Didaktika Religia, 7(2), 349-372. https://doi.org/10.30762/didaktika.v7i2.1550

Kusaeri, A. (2017). Berkah dalam perspektif al-qur'an (kajian tentang objek yang mendapat keberkahan) [UIN Syarif Hidayatullah Jakarta]. https://repository.uinjkt.ac.id/dspace/handle/123456789/3809o

Ma'arif, S. (2010). Pola Hubungan Patron-Client Kiai dan Santri di Pesantren. Ta'dib : Jurnal Pendidikan Islam, 15(2), 273-296. https://doi.org/10.19109/td.v15io2.76

Mas'ud, A. (2004). Intelektual pesantren : perhelatan agama dan tradisi. LKiS. 
Masrur, M. (2017). Figur Kyai dan Pendidikan Karakter di Pondok Pesantren. Tarbawiyah: Jurnal Ilmiah Pendidikan, 1(1), 272-282. https://doi.org/10.32332/tarbawiyah.v1i01.1022

Miskawaih, I. (1329). Tahdzibul achlaq wa tathhirul a'raaq. Husainiyah.

Mujib, A. (2006). Kepribadian dalam Psikologi Islam. RajaGrafindo Persada.

Munir, M. M. (2019). Sikap Tawadhu' Siswa SMP Terhadap Guru pada Pondok Pesantren Tanwirul Afkar Dusun Wadang Tempel Kecamatan Krian, Kabupaten Sidoharjo. Spiritualita: Journal of Ethics and Spirituality, 3(2), 217-238. https://doi.org/10.30762/spr.v3i2.1873

Musaropah, U. (2018). Kharisma Kyai Dalam Organisasi Pendidikan Pesantren Tradisional. Ulumuddin: Jurnal Ilmu-Ilmu Keislaman, 8(2), 141-155. https://doi.org/10.47200/ulumuddin.v8i2.193

Nata, A. (2001). Perspektif Islam tentang pola hubungan guru-murid studi pemikiran tasawuf-Al-Ghazali. Jakarta : RajaGrafindo Persada.

Nurbakhsy, J. (1998). Psikologi Sufi. Fajar Pustaka Baru.

Putrihapsari, R., \& Dimyati, D. (2021). Penanaman Sikap Sopan Santun dalam Budaya Jawa pada Anak Usia Dini. Jurnal Obsesi : Jurnal Pendidikan Anak Usia Dini, 5(2), 20592070. https://doi.org/10.31004/obsesi.v5i2.1022

Rahmat, A. (2007). Kesesatan Dalam Perspektif Al-Qur'an: Kajian Tematik terhadap Istilah"Dajal" dalam Al-Qur'an. Pustaka Pelajar.

Rahmatullah, A. S. (2013). Kecerdasan Interpersonal dalam Al-Quran dan Urgensinya Terhadao Bangunan Psikologi Pendidikan Islam. Cendekia: Journal of Education and Society, 11(1), 1-17. https://doi.org/10.21154/cendekia.v11i1.671

Rahmatullah, A. S. (2017). Upaya Penguatan "Motivasi Berakhlakul Karimah" Terhadap Peserta Didik Beribu Nenek dengan Pembelajaran Kitab Ta'lim Muta'alim (Studi di MTs Plus Nururrohmah Tambaksari Kuwarasan Kebumen, Jawa Tengah). JMKSP (Jurnal Manajemen, Kepemimpinan, Dan Supervisi Pendidikan), 1(2), 146-158. https://doi.org/10.31851/jmksp.v1i2.1015

Rozak, P. (2017). Indikator Tawadhu dalam Keseharian. Jurnal Ilmiah Madaniyah, 7(1), 174187.

Sumantri, E. (2007). Pendidikan Nilai Kontemporer. Program Studi PU UPI.

Thoriqussu'ud, M. (2012). Model - Model Pengembangan Kajian Kitab Kuning di Pondok Pesantren. Jurnal Ilmu Tarbiyah "At-Tajdid," 1(2), 225-239.

Y.M., K. (2017). Pendidikan Nilai dalam Pendidikan Nasional. Journal Analytica Islamica, 6(2), 155-161. http://jurnal.uinsu.ac.id/index.php/analytica/article/view/1280/1043

Zaqiah, Q. Y., \& Rusdiana, A. (2014). Pendidikan Nilai: Kajian Teori dan Praktik di Sekolah. Pustaka Setia.

Zuchdi, D. (2010). Humanisasi Pendidikan: Menemukan Kembali Pendidikan yang Manusiawi. Bumi Aksara. 